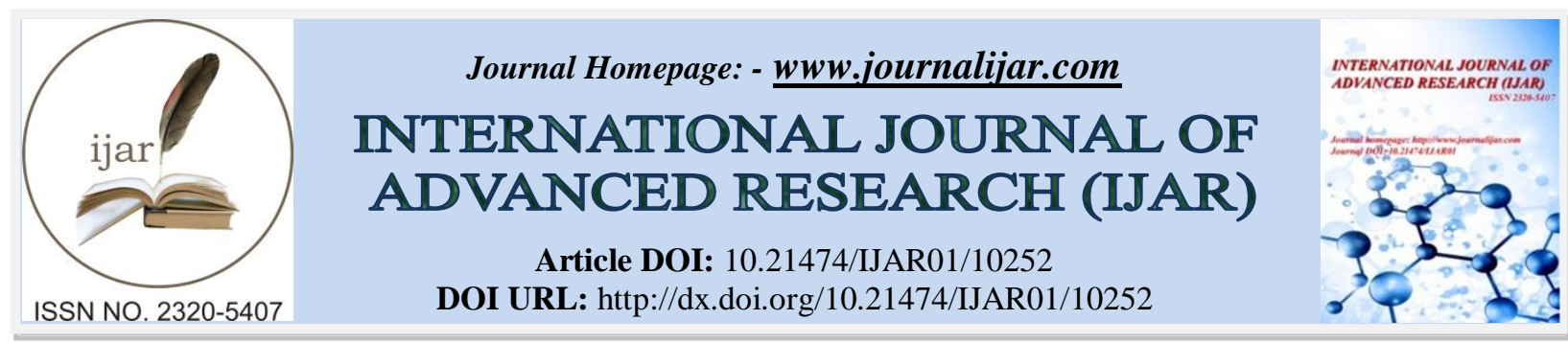

RESEARCH ARTICLE

\title{
USE OF THE RESULTS OF OPERATIONAL INVESTIGATIVE ACTIVITIES AT THE PRELIMINARY INVESTIGATION
}

Haydarov Mansur Mahmudjonovich

\section{Manuscript Info}

Abstract

Manuscript History

Received: 14 October 2019

Final Accepted: 16 November 2019

Published: December 2019

\section{Introduction:-}

The problems of criminal procedural evidence are always in the spotlight, both by scholars and practitioners. The institution of criminal procedural evidence, due to its importance and significance for criminal proceedings, must correspond to objective reality.

The process of proof is the core of any criminal case. In the past few years, the theory and practice has been aggressively developing the idea of the need for active use in criminal proceedings of the information obtained in the course of operational investigative activities, including their conversion into judicial evidence.

The problem we have touched on in the theory of criminal procedure and operational investigative activity has many approaches. So, E.A. Dolya the share indicates that the presence of different points of view, discussions on this problem should be considered as a stage on the way to its correct solution [1].

The urgent need to improve the procedure for entering into criminal proceedings information obtained during the implementation of operational-search measures requires legislative intervention. First of all, this is due to the fact that, in practice, during the trial, the results of the operational investigative activities, or the evidence derived from them, are often recognized as unacceptable.

When resolving the issue of using information obtained promptly as evidence, it is first necessary to proceed from the provisions of the criminal procedure legislation, because the criminal procedure in the territory of the Republic of Uzbekistan is established only by the CPC based on the Constitution of the Republic of Uzbekistan. Thus, the Law of the Republic of Uzbekistan "On operational-search activity" cannot and should not interfere with the work of the institute of criminal procedure evidence, or contradict its provisions. The operative-search legislation in this case is an auxiliary normative legal act, which is designed to help preliminary investigation bodies solve crimes [2]. We agree that the results of the Law on the operational investigative activities should be promoted and used in proving in a criminal case, since they cannot replace evidence, since they are deprived of procedural evidentiary power.

Thus, the Supreme Court of the Republic of Uzbekistan in the Resolution of the Plenum of August 24, 2019 in paragraph 9 indicated that the evidence is recognized as inadmissible also in cases of their receipt in violation of the requirements of the CPC, including if collected in violation of the requirements provided for by the Law of the Republic of Uzbekistan " On operational-search activity". That is, the supreme judicial body of the state recognizes 
that the provisions of the Law on the operational investigative activities do not regulate criminal procedural relations, and therefore the relations associated with the receipt, verification and evaluation of evidence [3].

At the same time, as can be seen from the above ruling of the Plenum of the Supreme Court, the CPC does not prohibit the use of the results of the of the Law on the operational investigative activities in the process of proving if they meet its requirements. The results of the Law on the operational investigative activities, presented for use in evidence in criminal cases, should allow the formation of evidence that meets the requirements of the criminal procedural law presented for evidence in general, for the corresponding types of evidence; contain information that is important for establishing the circumstances to be proved in a criminal case, indications of an operational search activities during which the alleged evidence was obtained, as well as data to verify the evidence generated on the basis of the criminal proceedings [4].

The results of the criminal investigations, documented prior to the initiation of a criminal case, when sent to the investigator in accordance with the Law "On operational-search activity" at this stage are not evidence in the criminal procedural sense, since they do not meet the requirements for criminal procedure legislation (see Article 81 of the Code of Criminal Procedure).

But under certain conditions, the results of an of the Law on the operational investigative activities may become evidence. By such conditions V.I. Zazhitsky with reference to V.Ya. Dorokhova calls the following: 1) information of an operational-search nature must be relevant to the criminal case and establish the presence and absence of the crime, the guilt of the accused and other circumstances relevant to the proper resolution of the criminal case; 2) information relating to the criminal case must be admitted to the criminal process in the foperational search activities prescribed by law. Such information can only be obtained from legal sources (part 2 of article 81 of the CPC), the list of which is exhaustive; 3 ) entry into the criminal process of information relating to the criminal case must be carried out in the manner prescribed by law for each type of evidence.

Thus, the information obtained during the execution of the operational search activities can become evidence if the above conditions are met and only after the investigator performs strictly defined procedural actions that are regulated by the criminal procedure law.

So, the investigator, guided by the relevant articles of the Code of Criminal Procedure, must inspect the materials submitted by the operational unit (in paper or electronic form) with the mandatory drawing up of a protocol of this investigative action in accordance with Art. 135 Code of Criminal Procedure.

The next obligatory procedural action of the investigator should be the inclusion of the results of the Law on the operational investigative activities into the criminal case as evidence, if the information contained in them is important for establishing the circumstances specified in the CPC. For this, the investigator makes an appropriate decision. And only after the results of the Law on the operational investigative activities have received the legal status of evidence in a criminal case, the investigator or judge can check them in accordance with Art. 90-95 Code of Criminal Procedure for admissibility.

It follows from the foregoing that the results of the Law on the operational investigative activities may become admissible evidence after investigative and other procedural actions in the criminal case are initiated, and only after that they can be transferred to the court, which will put them in the basis of the conviction.

Often, in practice, the investigating authorities do not carry out the necessary procedural steps to introduce and attach information obtained by operational means as evidence [6]. It turns out that the results of the Law on the operational investigative activities foperational search activities the evidence base in the criminal case, but they themselves did not receive the procedural status of evidence at the stage of the preliminary investigation. However, in the future they are provided as evidence at the stage of the trial, where the court, guided by the rules of the Code of Criminal Procedure, must recognize such information as unacceptable evidence, which may result in the release of the defendant from criminal liability.

It is worth noting that some scholars deny the possibility of recognizing operational and service materials obtained in the course of the performance of an Law on the operational investigative activities as such type of evidence as other documents. We believe that the current legislation does not prevent the use of documents received by 
operational units before initiating a criminal case in proving in criminal cases in the procedural mode this type of evidence - like other documents. This opinion is shared by many prominent scientists.

At the same time, it should be noted that there are cases in law enforcement practice where the courts, when passing a guilty verdict, relied on this kind of "quasi-evidence" [9]. We consider this ignoring the requirements of the law unacceptable, and the actions of officials unlawful. Note that such legal errors can lead to negative consequences in criminal proceedings.

It seems interesting and important to consider the issue of the possible use as evidence of information obtained during an operational search activities in violation of the law governing of the Law on the operational investigative activities.

When examining evidence (in particular, information obtained during the ORM) from the point of view of their criminal procedural admissibility, the court, prosecutor, investigator, interrogating officer shall recognize the evidence as admissible or inadmissible. In Art. 95 of the Code of Criminal Procedure, the inadmissibility of evidence is associated with a violation of the said Code itself, therefore, with a literal interpretation of this norm, violations of the legislation of the Law on the operational investigative activities are not covered by this article.

Some process scientists believe that if the rules for conducting an operational search activities stipulated by of the Law on the operational investigative activities have been violated (for example: the absence of a resolution approved by the head of the body carrying out of the Law on the operational investigative activities to conduct a test purchase, or a court decision when carrying out activities that significantly affect rights and the legitimate interests of citizens), their results after verification by a procedural means can be used in evidence in a criminal case.

They substantiate their position by the fact that, according to the Criminal Procedure Code, there are no obstacles for introducing into the criminal case information enshrined in the legalized sources of evidence, including those obtained in violation of the Law on Operational Investigation Activities, with their subsequent verification, assessment and use of the procedure provided for criminal procedure legislation. Evidence obtained in this way in the criminal process will be checked and evaluated, like any other.

It seems that the above arguments have no legal basis. And the conclusions made by the authors are based on a misinterpretation of the law. We add that a similar situation is a priori impossible in a democratic, rule-of-law state, where a person, his rights and freedoms are the highest value. In turn recognition, observance and protection of human rights and freedoms are the responsibility of the state.

The criminal procedural admissibility of evidence, which is based on the results of the ORM, implies compliance with the rules of the Criminal Procedure Code when collecting, checking and evaluating evidence and at the same time complying with the procedure for obtaining the results of the Law on the operational investigative activities with operational-search standards.

So, V. Znikin notes that a derogation from the requirements of legislative acts regulating the grounds and conditions for conducting operational search activities leads to the fact that the results of their implementation in the interests of criminal proceedings cannot be used [13]. We believe that the results of the warrants obtained in violation of the norms of the operational-search legislation cannot be introduced into the criminal case as evidence, since the evidence remains valid only if the rules of the CPC are not violated during their collection and consolidation, and the results of the warrant were obtained in compliance with applicable law.

For example, A.A. Kupriyanov claims that: “... the results of the ORM, during which damage to the facility's health was done, should be recognized in the established order as unacceptable evidence even at the stage of criminal proceedings or during the investigation as inconsistent with the law".

However, we cannot support this point of view, as this may lead to "abuse of the right". Suppose that a person against whom an operational search activities was carried out, as a result of which information was obtained that incriminates his criminal activities and which should become evidence in a criminal case, he declares in court that his health was undermined during the production of operational search activities (nervous breakdowns, jumps in blood pressure, various cardiovascular diseases, etc.). Although the status of a suspect or accused person already 
leads a person into a stressful situation that could negatively affect his health, this should not be an obstacle to criminal prosecution, since evidence obtained with damage to the object's health will be declared inadmissible.

So, the Law on Horde in Art. 16 stated that "while protecting the life and health of citizens, their constitutional rights and legitimate interests, as well as to ensure the safety of society and the state from criminal encroachments, involuntary harm to law enforcement interests is allowed ..."

Despite the many different and opposing opinions regarding the issues we are considering, we agree with V.I. Zazhitsky, who rightly noted that successfully solving the problem of using the results of the Law on the operational investigative activities in proving criminal cases, can only be guided by the existing evidence law, and not on the basis of abstract and abstract representations [18].

It seems that the current legal regulation of the use of the results of the Law on the operational investigative activities in criminal proceedings, in our opinion, has a number of significant drawbacks that we considered in this work.

We believe that it is necessary to amend the Code of Criminal Procedure and the Law on the operational investigative activities, thereby eliminating the shortcomings that make it possible to use the unacceptable evidence obtained in the course of the operational search activities in criminal proceedings:

1. Art. 95-1 of the Code of Criminal Procedure shall be reworded as follows: "Article 89. Use of the results of operational investigative activities in evidence.

2. The results of operational investigative activities may be used in proving criminal cases in accordance with this Code.

3. In the process of proof, the use of the results of operational-search activities is prohibited if:

4. such results do not meet the requirements for evidence by this Code;

5. such results were obtained in violation of the law "On operational-search activity".

6. Add a new article 101 "Results of operational investigative activity" to the Law on the operational investigative activities.

\section{List of References:-}

1. Agafonova Yu.A. Fundamentals of operational-search activities of the internal affairs bodies: textbook. / ed. Yu.A. Agafonova, Yu.F. Kvashi. - Krasnodar: Krasnodar. University of the Ministry of Internal Affairs of Russia, 2007.

2. Share E.A. The results of operational investigative activities cannot become the content of evidence in criminal proceedings // State and Law. - 2013. - No. 5. - S. 24-29.

3. Zazhitsky V.I. About use in proving the results of operational investigative activity // State and Law. - 2010. No. 7. - S. 61-71.

4. Znikin V. The results of the war in the criminal process // Legality. - 2005.-№ 11.

5. Constitution of the Republic of Uzbekistan. Tashkent. 2019.

6. Kupriyanov A.A. Protecting the health of citizens in the implementation of operational investigative activities // Criminal process. - 2011. - No. 1. - S. 16-19.

7. Law of the Republic of Uzbekistan "On operational-search activity".

8. The Code of Criminal Procedure of the Republic of Uzbekistan.

9. The criminal process: textbook. / A.V. Smirnov, K. B. Kalinovsky; under the general. ed. prof. A.V. Smirnova. - 4th ed., Revised. and add. - M .: Knorus, 2008. 